\author{
Abstracta Iranica \\ Abstracta Iranica Revue bibliographique pour le domaine irano-aryen \\ Volume 40-41 | 2019 \\ Comptes rendus des publications de 2017-2018
}

\title{
Jan Dušek. "Languages and Scripts of Samaria in the Persian and Hellenistic Periods"
}

\section{Astrid Nunn}

\section{(2) OpenEdition}

\section{Journals}

Édition électronique

URL : http://journals.openedition.org/abstractairanica/48340

DOI : 10.4000/abstractairanica.48340

ISBN : 1961-960X

ISSN : 1961-960X

Éditeur :

CNRS (UMR 7528 Mondes iraniens et indiens), Éditions de l'IFRI

Référence électronique

Astrid Nunn, "Jan Dušek. "Languages and Scripts of Samaria in the Persian and Hellenistic Periods" », Abstracta Iranica [En ligne], Volume 40-41 | 2019, document 30, mis en ligne le 15 juillet 2019, consulté le 22 avril 2021. URL : http://journals.openedition.org/abstractairanica/48340 ; DOI : https://doi.org/ 10.4000/abstractairanica.48340

Ce document a été généré automatiquement le 22 avril 2021

Tous droits réservés 


\title{
Jan Dušek. "Languages and Scripts of Samaria in the Persian and Hellenistic Periods"
}

\author{
Astrid Nunn
}

\section{RÉFÉRENCE}

Jan Dušek. "Languages and Scripts of Samaria in the Persian and Hellenistic Periods" in Ulrich Hübner, Herbert Niehr (Hg.). Sprachen in Palästina im 2. und 1. Jahrtausend v. Chr. Kolloquium des Deutschen Vereins zur Erforschung Palästinas, 02.-04.11.2012, Mainz. Wiesbaden: Harrassowitz Verlag, 2017, p. 121-151

Samarie a été intégrée à l'Empire achéménide en 539 av. J.-C., date à partir de laquelle les inscriptions sont surtout en araméen et rarement en hébreu. L'A. donne un aperçu sur les porteurs très variés de l'araméen: scellements de jarre, quelques tessons, les "papyrus de Samarie" du Wadi ed-Daliye et les monnaies. L'hébreu se trouve surtout sur les monnaies. Malgré l'influence de la Phénicie et l'usage de monnaies phéniciennes, le phénicien ne fut pas écrit à Samarie.

\section{AUTEURS}

\section{ASTRID NUNN}

Université de Munich 